\title{
Ownership and Use of Mobile Phone Among Farmers in North Senatorial Zone of Kaduna State.
}

\author{
Haruna, S.K., Jamilu,A.A., Abdullahi, A.Y. and Murtala, G.B. \\ National Agricultural Extension and Research Liaison Services (NAERLS), Ahmadu Bello \\ University, P.M.B.106, Zaria, Nigeria \\ E-mail:salisukura@gmail.com Mobile Phone No.08026929746
}

\begin{abstract}
The study examined the use of mobile phone by farmers in selected communities of North Senatorial Zone of Kaduna State. Interview schedule was used to collect data from a sampled of 120 respondents. Percentage, frequency and mean score were used in analyzing data. The results showed $72 \%$ of the respondents attended primary to tertiary level of education with about $62 \%$ having farming experienced of over 15years. Majority of the respondents were engaged in farming as their primary occupation. Most (66\%) owned mobile phone and found it very effective in sourcing and sending information regarding to their farming business. High cost of service charges, poor quality of mobile phone and its accessories were the top ranking constraints against the effective usage of mobile phone. The study concluded that for farmers to use mobile phone effectively for extension communication, all the constraints to its effective use need to be seriously addressed.
\end{abstract}

Keywords: Farmers, ownership, usage, mobile phone, ICT, agricultural extension transformation agenda and Kaduna State.

\section{Introduction}

Mobile phone provides existing new ways through which extension workers can reach farmers in rural areas that have in the past been very difficult to contact, particularly in developing countries like Nigeria. Ownership and use of mobile phone among the rural farmers has continued to increase thereby increasing the chances of contacting farmers in their communities for extension activities. Mobile phones are fast becoming the new tool for agricultural extension service. Globally, traditional agricultural extension systems are in decline, while the number of farmers has increased and now stands at around 2.6 million, the number of extension workers has decreased to approximately 500,000 (Gakuru et al., 2009, Anderson \& Fedder, 2007; Aker, 2011). In the past, the major means of information dissemination in developing countries to farmers has been through magazines, newspapers, posters, bulletins, radio, television etc. Food and Agricultural Organization (FAO,1993) and Greenidge (2003) defines ICT as technologies involved in collecting, processing, storing, retrieving, disseminating and implementing data and information using microelectronics, optics and telecommunications and computers. According to the Technical Centre for Agricultural and Rural Cooperation (CTA, 2003) ICT can be interpreted broadly as technologies that facilitate communication and the processing and transmission of information by electronic means of which mobile phone is inclusive.

Emanuel (2010) in a study conducted on the differential mass media use among rice farmers in Benue state concludes that ICT has played a major role in diffusing information to rural communities. Omotayo (2011) notes that access to information has the potential to transform agriculture and rural dwellers by contributing to poverty alleviation, food security, and creation of employment opportunities and informed decision making by all. 
Karamagi et al. (2009) in a study of the adoption of mobile phones by dairy farmers in rural Uganda highlights the ability of mobile phones to provide information advantage and encourage greater efficiency. Rogers (2003) asserts that individuals who are higher in socioeconomic status are able to adopt innovation much more quickly than those with lower levels of education and fewer assets. However, Brandie et al., (2008) found a negative relationship between level of education completed and the length of time owning mobile phone among mobile phone users. The result indicates that education level was not significant in impacting earlier adoption of mobile phone. Bolarinwa et al. (2011) showed that frequency of contact with Agricultural Information Centers revealed that cell phone user farmers had greater mean score of X41.43 contact as against the low means scores X19.32 contact recorded by farmers receiving agricultural information from extension agents not using cell phone and their production was statistically significant at $P<0.05$. He concludes that the usage of cell phone has increased extension agent contact and increased farmer's production capacity. Despite the adoption of Mobile Phone by extension workers and farmers' for disseminating information in developing countries is use is still very seriously limited particularly in the rural areas.

Arokoyo (2005) and Anthony (2007) identified poor ICT infrastructural facilities, erratic and unstable power supply and high cost of alternative power supply through standby generators, limited and high cost of telephone services, limited access to computers and internet and lack of communication policy by government of most developing countries as constraints to the effective us of ICT facilities in developing countries. Bolarinwa (2011) identified high call tariff, fluctuating service, erratic power supply, high cost of handset, Cost of recharge cards, network coverage, repair of technical fault and access to recharge purchasing centre as constraints to use of cell phone in Nigeria.

In spite of urge for farmers ownership and usage of mobile phone which is considered very essential for successful transformation of agriculture not in Kaduna state alone but Nigeria in general, yet little is known about farmers' status of mobile accessibility and utilization. The specific objectives of the paper was; (i) examine mobile phone ownership and use to source agricultural extension information; (ii) assess farmers' perception of the effectiveness of mobile phone usage in extension information sourcing; and (iv) identify constraints to effective use of mobile phone by farmers.

\section{Methodology}

The study was conducted in the North Senatorial zone of Kaduna State. It comprises of eight local government areas (LGAs). The major ethnic groups in the study area include: Hausa, Fulani, Kadara, Kurama. English and Hausa language are widely spoken (NAERLS, 2010).

A multistage sampling technique was employed. Three LGAs were purposively selected because of farming intensity. They included: Makarfi, Soba and Lere respectively. In the second stage, four villages from each LGAs were randomly selected, giving a total of twelve villages, namely: Gubuchi, Mayere, Nasarawan_-Doya and Gimi in Makarfi LGA; while Turawa, Wanka, Yakasai and Richifa from Soba LGA and Saminaka, Dan-Alhaji, Yarkasawa and Garu from Lere L.G.A. Subsequently,

ten farmers from each village were randomly selected, this gave a sample sizeof 120 respondents. Primary data was generated by using structured questionnaire, and information collected included, socio-economic characteristics of the respondents such as age, gender, educational level and family size. Also data was collected on accessibility, usage and constraints to effective mobile phone usage. 
Descriptive, Statistics such as frequency, percentage and mean were employed to achieve objectives i, ii and iv, 4 likert scale score was used to achieve objective iii. In determining the perception of farmers on the effect of mobile phone usage, the mid-point values of the perceived effect were summed and further divided by 4 to obtain the mean value of 2.5 . Any perceived effect less than 2.5 is considered not effective, where as any value equal to or greater than 2.5 is considered effective..

\section{Result and Discussion}

\section{Socioeconomic characteristics of the respondents}

The result in Table1 shows that most $(34.2 \%)$ of the respondents were in the age bracket of $36-45 y e a r s$, while the least $(9 \%)$ of the respondents were below 25 years old. The finding also revealed that average age of respondents is 41 years old. This confirmed that younger people are engaged in agriculture. This finding is consistent with the result of Anyanwu in Akinbile et-al (2007) eds, which indicated that active participant in farming are within the age range of $40-50$ years. The result in Table 1 also shows that $93 \%$ of the respondents were male indicating low participation of women in agriculture. This could be attributed to the period the study was conducted which coincided with the period when men were actively involved in the farm than female. Women normally provide labour during harvesting and other off farm activities.

Table 1 also shows that most $(43 \%)$ of the respondents went up until secondary school with only $15 \%$ of the respondents attended tertiary level of education. Majorities $(80 \%)$ of the respondents were married and about $86 \%$ were engaged in farming as their primary occupation. The result in figure 1 also indicated that $46 \%$ had $11-20$ years of farming experience, while 36 percent had household size of $6-10$ members and 44 percent cultivated up to 1.9 hectares of farm land. 
Table 1: Socioeconomic characteristics of farmers

\begin{tabular}{|c|c|c|}
\hline \multirow{2}{*}{\multicolumn{3}{|c|}{$\begin{array}{l}\text { Socioeconomic variables } \\
\text { Age }\end{array}$}} \\
\hline & & \\
\hline$\leq 25$ & 9.1 & \\
\hline $26-35$ & 18.3 & \\
\hline $36-45$ & 34.2 & 40.9 \\
\hline $46-55$ & 23.3 & \\
\hline$\geq 56$ & 15.0 & \\
\hline \multicolumn{3}{|l|}{ Gender } \\
\hline Male & 94.2 & \\
\hline Female & 5.8 & \\
\hline \multicolumn{3}{|l|}{ Educational level } \\
\hline Adult education & 31.6 & \\
\hline Primary & 17.6 & \\
\hline Secondary & 35 & \\
\hline Tertiary & 15.8 & \\
\hline \multicolumn{3}{|l|}{ Marital status } \\
\hline Married & 80 & \\
\hline Single & 18.3 & \\
\hline Divorce & 15.8 & \\
\hline \multicolumn{3}{|l|}{ Household size } \\
\hline$\leq 5$ & 32.5 & \\
\hline $6-10$ & 35.8 & 8.9 \\
\hline $11-15$ & 21.7 & \\
\hline$\geq 16$ & 10 & \\
\hline \multicolumn{3}{|l|}{ Primary occupation } \\
\hline Farming & 85.8 & \\
\hline Civil service & 6.7 & \\
\hline Artisan & 1.7 & \\
\hline Trading & 5.8 & \\
\hline \multicolumn{3}{|l|}{ Farming experience } \\
\hline$\leq 10$ & 29.1 & \\
\hline $11-20$ & 46.4 & 17.1 \\
\hline $21-30$ & 11.5 & \\
\hline$\geq 31$ & 13 & \\
\hline \multicolumn{3}{|l|}{ Farm size } \\
\hline$\leq 1 \mathrm{ha}$ & 27.5 & \\
\hline 1 to 1.9 & 44.2 & \\
\hline 2 to 2.9 & 11.7 & 1.8 \\
\hline 3 to 3.9 & 7.5 & \\
\hline$\geq 4$ & 9.2 & \\
\hline
\end{tabular}

Source: Field survey, 2012

Farmers' ownership and use of mobile phone tools to seek for agricultural extension information

The result in Figure 1 indicates that majority (66\%) of farmers owned mobile phone. An increasing need for new and different types of information on agriculture, literacy level, experience in agriculture and farming being the major occupation could be the likelihood of farmers owing a mobile phone; while on the other hand, $34 \%$ of the respondents do not owned mobile phone. Moreover Figure 2 shows that $57 \%$ of the respondents used mobile, more frequently, this is an indication that there is a relationship between mobile phone ownership and usage. Table 2 illustrates that $75,65.2,55.7$ and $43 \%$ of farmers who owned 
mobile phone used it mobile phone call tools to source information to get access to good markets, consult experts, emergency help and inputs procurement respectively. This is an expected development since it portrayed the significance of mobile phone in agriculture. The result is in line with the findings of Aker, (2008) and Okello,(2011), which indicate that farmers/traders of agricultural produce (grains) who gained access to mobile phone use it to seek market information. However, the result shows that not more than $9.2 \%$ of the respondents used text message a mobile phone tool to get information on extension services. This is a great challenge to ATA e-wallet fertilizer allocation to farmers. As such, much need to be done to develop farmers' capacity to effectively use mobile phone tools.

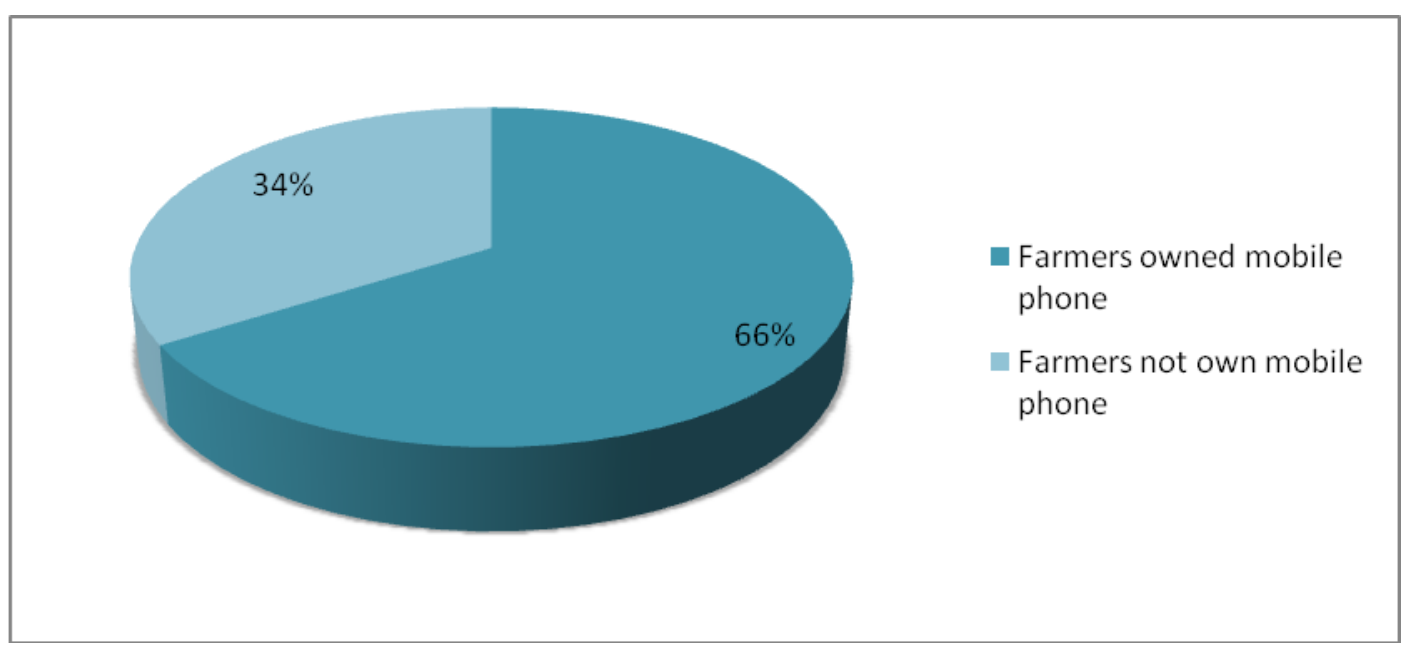

Figure 1: Farmers' Mobile Phone Ownership.

Source: Field survey, 2012

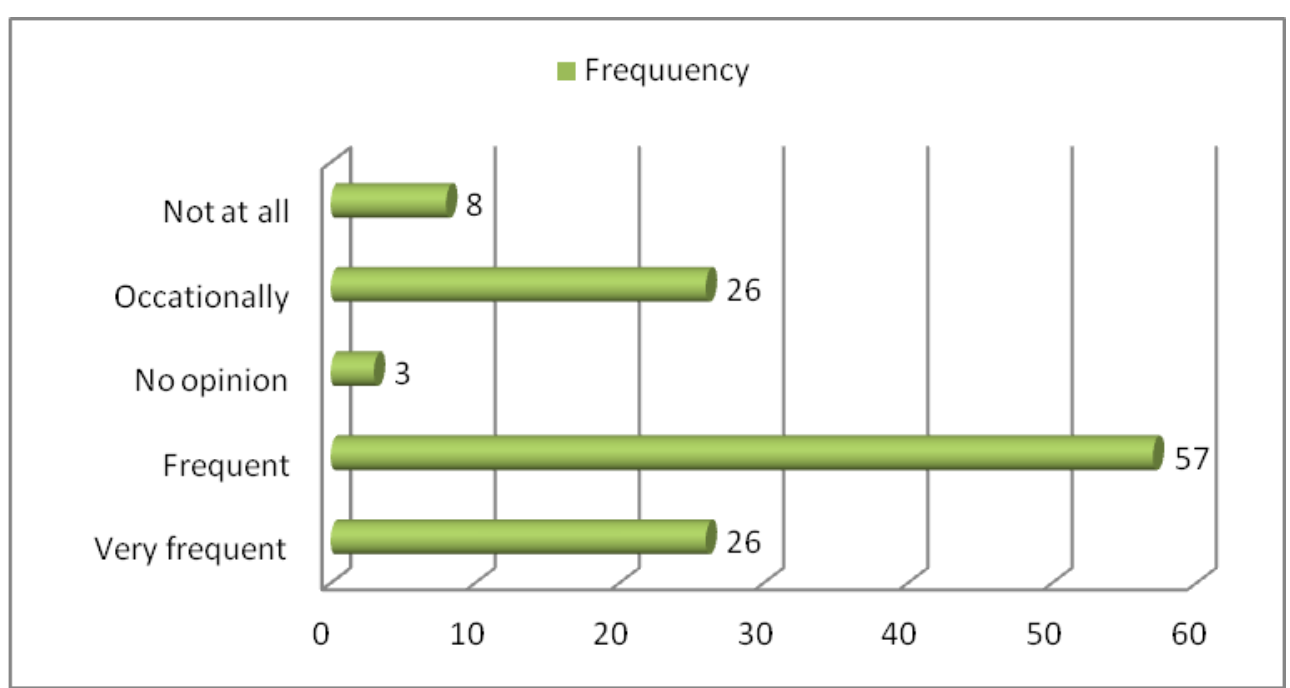

Figure 2: Frequency of Mobile usage by farmers

Source: Field survey, 2012 
Table 2: Proportion of Farmers Using Mobile Phone Tools to Seek Information on Agriculture

\begin{tabular}{llc}
\hline Source of information & Scope of usage & Percentage \\
\hline Getting access to inputs & Making a call & 43 \\
& Text messaging & 9.2 \\
& Making a call and Text & 13.8 \\
& messaging & 25.7 \\
& Non phone tools & 75 \\
Getting access to markets & Making a call & 19.2 \\
& Text messaging & 41.8 \\
& Making a call and Text & 25.7 \\
& messaging & 65.2 \\
Call for emergency help & Non phone tools & 7.2 \\
& Making a call & 51.8 \\
& Text messaging & 55.7 \\
& Making a call and Text & 23 \\
& messaging & 9.2 \\
Consult expert advise & Non phone tools & 31.8 \\
& Making a call & 65.4 \\
\hline & Text messaging & \\
\hline
\end{tabular}

Source: Field survey, 2012

Farmer perception on the effectiveness of mobile phone usage for extension information sourcing

Table 3 shows farmers' perception on the effectiveness of mobile phone as a means of sourcing information regarding extension service delivery. Credit sourcing, input procurement and marketing of farm produce information were particularly perceived by farmers to effectively reach them through mobile phone. This result is in line with the findings of Gaurall, (2009). and Furuholt et al. (2011) which assert that the use of mobile phone enables farmers to access information from various sources such as research institutes, inputs dealers, government agencies, agricultural extension officers, veterinary doctors' traders and even consumers of their products. They affirmed that mobile phones affected all stages of the farming cycle which include preparation, farming, harvesting and post-harvest. This finding supports the studies conducted by Hudson, (2006) and Saunders et al. (1994), who indicated that mobile phone is not only adopted for social reasons, but is viewed by the farmer as a tool that will allow for more efficient and informed action to enhance greater productivity. 
Table 3: Farmer perception on the effectiveness of mobile phone usage for extension information sourcing

\begin{tabular}{lll}
\hline Quality of information & Weighted sum & Weighted mean \\
\hline & 387 & $3.2^{*}$ \\
Input procurement $(n=120)$ & 374 & $3.1^{*}$ \\
Credit sourcing $(n=120)$ & 369 & $3.0^{*}$ \\
Marketing of agricultural produce $(n=120)$ & & \\
Pest and diseases management $(n=120)$ & 292 & 2.4 \\
storage and processing $(n=120)$ & 320 & $2.6^{*}$ \\
Utilisation of farm produce $(n=120)$ & 241 & 2.0 \\
Farm operations $(n=120)$ & 316 & $2.6^{*}$ \\
\hline
\end{tabular}

Source: Field survey, 2012; *Figures in parentheses are percentages

\section{Constraints to effective mobile use by farmers}

Table 4 shows that about $78 \%, 68 \%$ and $62 \%$ of the respondents reported high cost of subscription charges, poor quality of mobile phone and its accessories and power problem, to be major constraints. Other constraints identified included; high cost of maintenance, poor network and inadequate skill for its operation. This finding reckons with that of Bolarinwa (2011), Arokoyo (2005) and Anthony (2007) which identified high call tariff, fluctuating service, erratic power supply, high cost of handset, cost of recharge cards, network coverage, repair of technical fault and access to recharge purchasing centers as constraints to effective use of cell phone in Nigeria.

Table 4: Constraints to effective mobile phone usage

\begin{tabular}{lcc}
\hline Constraints & $\begin{array}{l}\text { Percentage } \\
(\mathbf{n = 1 2 0 )}\end{array}$ & Rank \\
\hline Poor net work & 48.3 & 5 \\
Lack of service & 7.5 & 7 \\
Electricity problem & 62.5 & 3 \\
High cost of subscribe charges & 77.5 & 1 \\
Inadequate skill for its operation & 29.2 & 6 \\
Poor quality of mobile phone and its accessories & 68.3 & 2 \\
High cost of maintenance & 56.7 & 4 \\
\hline
\end{tabular}

\section{Source: Field survey, 2012}

\section{Conclusion}

From the findings of the study it can be concluded that the age group of 36-45 accounted for the highest (34\%) of the respondents, while the least below 25 years accounted for only $9 \%$ of the respondents. This confirmed that in the study area younger people are engage in agriculture. Similarly majority of farmers owned and use mobile phone for making call, view time and used it for calculation frequently. As regard farmers' perception of mobile phone as an effective means of sourcing information regarding extension service delivery, many of them agreed that it's an efficient and effective facilities for extension communication. High cost of subscription, Poor quality of mobile phone and its accessories and electricity problems were the top ranked constraints against effective usage of mobile phone among farmers in the study area. 


\section{Recommendation}

Based on the findings of this study, the following recommendations were made:

(i) More training should be plan and properly carried out in the study area in particular and nationwide in general, to train and update farmers' skill on how to send messages using mobile phones.

(ii) Charges on air time to be reduce to the barest minimum;

(iii) Mobile phones using solar batteries should be introduced;

(iv) Good quality mobile phones and accessories should be produced and should be made available.

\section{Reference}

Aker, J.C (2008a). Does digital divide or provide: The impact of cell phones on grain markets in Niger. BREAD Working Paper No.177.

Akinbile, L.A., Salimonu K.K, and Yekinni O.T (2007), Farmers participation in Agroferestry Practices in Ondo State, Nigeria, Research Journal of Applied Science, 2(3): 229-232.

Anderson, J. and Feder, G. (2007). Agricultural Extension Handbook of Agricultural Economics, Vol. 3 Everson R.E., Pinyali, P. (eds), Elsevier Science, Amsterdam, The Neitherlands 2343-2378.

Anthony, O.A., (2007). Agricultural Extension A Pathway for Sustainable Agricultural Development, Loud Books/Apani Publication.

Arokoyo, T.J. (1998). Agricultural Technology Development and Dissemination. A case study of Ghana and Nigeria Experiences. CTA (ACP-EU), Wageningen, The Netherlands.

Bolarinwa, K.K. and Oyeyinka, R.A. (2011). Use of Cell Phone by farmers and its implication on farmers' Production Capacity in Oyo State Nigeria. In: World Academy of Science, Engineering and Technology 512011.

Emmanuel, C.O. (2010). Differential Mass Media Usage among Rice Farmers in Nigeria Evidence from Benue State. In Journal of Communication, 1(1): 33-36

Food and Agriculture Organizations (1993): The Potentials of Microcomputers in Support of Agricultural Extension, Education and Training. Rome, FAO.

Gakuru, M., Winters, K. and Stepman, F. (2009). Inventory of Innovative Farmers advisory services using ICTs. Forum for Agricultural research Africa (FARA), Accra, Ghana.

Greenidge, C.B. (2003). Information Communication Technologies and the Rural Sector in ACP States: Mirage or Marriage? Features Address Delivered at the CTA's ICT Observatory 2003.

Hudson, H. (2006). From rural village to global village: Telecommunications for development in the information age. Danbury, CT: Lawrence Erlbaum.

National Agricultural Extension and Research Liaison Services (NAERLS) and National Food Reserve Agency (NFRA) (2010). National report of Agricultural performance survey of 2009 wet season in Nigeria. Pp $157-172$

Okello, J.J. (2011). Use of information and communication tools and services by rural grain traders: The case of Kenyan maize traders. Intern. J. ICT. Res. Dev., 2: 39-53.

Omotayo, O.M. (2011). Information Communication technology and Agricultural Extension: Emerging Issues in Transferring Agricultural Technology in Developing Countries in: Agricultural Extension in Nigeria. A Publication of Agricultural Extension Society of Nigeria (AESON, 2011). 